\title{
Dantrolene in the treatment of MDMA-related hyperpyrexia: a systematic review
}

\author{
Brian E. Grunau, MD; ${ }^{*}$ Matthew O. Wiens, PharmD; ${ }^{\dagger}$ Jeffrey R. Brubacher, $\mathrm{MD}^{\ddagger}$
}

See related article on page 457

\section{ABSTRACT}

Objective: The use of dantrolene in the treatment of hyperpyrexia related to MDMA (3,4-methylenedioxymethamphetamine) is controversial, with little data available to guide clinical decision-making. Although the treatment is recommended by several poison control centres, published data are primarily in the form of case reports and animal and in vitro experiments. We conducted a systematic review to investigate the published evidence regarding the safety and benefits of dantrolene for MDMA-related hyperpyrexia in humans.

Data sources: A systematic search of Embase and MEDLINE was conducted from the earliest possible date to November 2008.

Study selection: All human trials and case reports of MDMArelated hyperpyrexia were considered.

Data extraction: Data were abstracted systematically and characteristics including use of dantrolene, adverse reactions attributed to dantrolene, peak temperature, complications from MDMA-related hyperpyrexia and survival were recorded.

Data synthesis: Our search yielded 668 articles of which 53, reporting 71 cases of MDMA-induced hyperpyrexia, met our inclusion criteria. No clinical trials, randomized controlled trials, observational studies or meta-analyses were identified. Dantrolene was used in 26 cases. Patient characteristics were similar in the dantrolene and no dantrolene groups. The proportion of survivors was higher in the dantrolene group $(21 / 26)$ than in the no dantrolene group (25/45). This difference was especially pronounced in those with extreme $\left(\geq 42^{\circ} \mathrm{C}\right)$ and severe $\left(\geq 40^{\circ} \mathrm{C}\right)$ fever, with a survival rate of 8 of 13 and 10 of 10 , respectively, in the dantrolene group compared with 0 of 4 and 15 of 27 in the no dantrolene group. There were no reports of adverse events attributable to dantrolene with the exception of a possible association with an episode of transient hypoglycemia.

Conclusion: Our systematic review suggests that dantrolene is safe for patients with MDMA-related hyperpyrexia. Dantrolene may also be associated with improved survival and reduced complications, especially in patients with extreme $\left(\geq 42^{\circ} \mathrm{C}\right)$ or severe $\left(\geq 40^{\circ} \mathrm{C}\right)$ hyperpyrexia, although this conclusion must be interpreted with caution given the risk of reporting or publication bias.

Keywords: MDMA, toxicology, dantrolene, MDMA-related hyperpyrexia

\section{RÉSUMÉ}

Objectif : L'utilisation du dantrolène dans le traitement de I'hyperthermie induite par la MDMA (3,4-méthylènedioxyméthamphétamine) est controversée et peu de données sont disponibles pour guider la prise de décision clinique. Bien que plusieurs centres antipoison en recommandent l'utilisation, les données publiées sont principalement sous forme de rapports de cas et d'expériences sur des animaux et in vitro. Nous avons effectué une revue systématique en vue d'analyser les données probantes concernant l'innocuité et les bienfaits de dantrolène pour traiter l'hyperthermie induite par la MDMA chez les humains.

Sources des données : Nous avons procédé à une recherche systématique des bases de données Embase et MEDLINE, de la date la plus lointaine possible à novembre 2008.

Sélection des études : Nous avons considéré toutes les études sur des humains et rapports de cas d'hyperthermie liée à la prise de MDMA.

Extraction des données : Nous avons extrait les données de façon systématique et avons pris en note les caractéristiques, dont l'utilisation de dantrolène, les effets indésirables attribués à ce médicament, la température maximale, les complications de l'hyperthermie induite par la MDMA et la survie.

Synthèse des données: Notre recherche a produit 668 articles dont 53 traitant de 71 cas d'hyperthermie induite par la MDMA répondaient nos critères d'inclusion. Nous n'avons repéré aucune étude clinique, étude contrôlée randomisée, étude d'observation ou méta-analyse. Le dantrolène a été utilisé dans 26 cas. Les caractéristiques des patients dans les groupes dantrolène et sans dantrolène étaient similaires. Le

From the *Department of Emergency Medicine, St. Paul's Hospital and the University of British Columbia, Vancouver, BC, the $†$ Department of Pharmacy, Chilliwack General Hospital, Chilliwack, BC, as well as the School of Population and Public Health, University of British Columbia, Vancouver, BC, and the ¥Department of Emergency Medicine, Vancouver General Hospital, University of British Columbia, Vancouver, BC

Submitted Jul. 23, 2009; Revised Nov. 23. 2009; Accepted Dec. 3, 2009

This article was peer reviewed.

CJEM 2010;12(5):435-42 
taux de survie était plus élevé dans le groupe dantrolène $(21 / 26)$ que dans le groupe sans dantrolène (25/45). On note une différence particulièrement importante chez les patients ayant une hyperthermie extrême $\left(\geq 42^{\circ} \mathrm{C}\right)$ ou grave $\left(\geq 40^{\circ} \mathrm{C}\right)$, avec un taux de survie de 8 sur 13 et de 10 sur 10 , respectivement, dans le groupe dantrolène, comparativement à 0 sur 4 et 15 sur 27 dans le groupe sans dantrolène. II n'y avait aucune notification d'effets indésirables attribuables au dantrolène sauf une association possible avec un épisode d'hypoglycémie transitoire.

Conclusion : Notre revue systématique suggère que le dantrolène est sécuritaire pour les patients présentant une hyperthermie induite par la MDMA. Le dantrolène peut également améliorer le taux de survie et réduire les complications, en particulier chez les patients présentant une hyperthermie extrême $\left(\geq 42^{\circ} \mathrm{C}\right)$ ou grave $\left(\geq 40^{\circ} \mathrm{C}\right)$, quoique cette conclusion doive être interprétée avec prudence vu le risque de biais de déclaration ou de publication.

\section{BACKGROUND}

MDMA (3,4-methylenedioxymethamphetamine), commonly referred to as "Ecstacy," was first introduced in 1914 by Merck \& Co., Inc., when patented as an appetite suppressant. ${ }^{1}$ It was used experimentally in psychotherapy in the 1970s and gained increased clinical significance with the advent of "raves" in the 1970s and 1980s. Since then, MDMA has gained popularity as a recreational drug because of its reputation of "safely" producing euphoric effects. In Canada, 3.0\% of women and $5.2 \%$ of men over the age of 15 report having "ever used or tried" MDMA. ${ }^{2}$ In the United States, $5.8 \%$ of high school students report use of MDMA one or more times in their life. ${ }^{3}$ In spite of the high prevalence of use, relatively few people report adverse effects from MDMA and the fatality rate among users aged 15-24 years has been estimated to be only $0.002 \%-0.053 \%$. $^{4}$

Despite its reputation as a safe drug, MDMA can cause severe toxicity and may produce a "hyperpyrexic syndrome," which may include severe hyperpyrexia, muscle rigidity, altered mentation, rhabdomyolysis, acute renal failure, lactic acidosis, hepatotoxicity, disseminated intravascular coagulation, multiorgan failure necessitating treatment in the intensive care unit and death. Many of the toxic effects of MDMA are thought to be serotonin mediated, producing a form of serotonin syndrome ${ }^{5}$ due to the blocking of serotonin reuptake. However, increases in synaptic dopamine and noradrenaline may also play a role. ${ }^{6,7}$ Although it would be expected that a dose-response relationship would exist between serum MDMA levels and toxicity, this does not appear to be true. ${ }^{8}$ Cases have been reported with serum levels as high as $7.72 \mathrm{mg} / \mathrm{L}$ with virtually no symptomatology and, conversely, fatalities have been reported with levels of $0.11 \mathrm{mg} / \mathrm{L}$.

Several theories have been suggested as to why most MDMA users experience only mild sympathomimetic effects while in rare cases patients present with hyperpyrexic syndrome. It has been considered for decades that MDMA-related hyperpyrexia may be caused by a similar mechanism as malignant hyperpyrexia, thereby only manifesting in those with a genetic predisposition. ${ }^{10,11}$ Malignant hyperpyrexia is an autosomal dominant myopathy triggered by volatile anesthetics and depolarizing muscle relaxants that is thought to involve the release of excess calcium from the sarcoplasmic reticulum causing muscle hypermetabolism. It has also been suggested that serotonin release may play a role in this process. ${ }^{12}$ Malignant hyperpyrexia is clinically similar to MDMA-related hyperpyrexic syndrome with muscle rigidity, rhabdomyolysis, lactic acidosis and hyperpyrexia. ${ }^{13}$ It was this logic that introduced the use of dantrolene, the treatment for malignant hyperpyrexia through inhibition of $\mathrm{Ca}^{2+}$ release, as a treatment for MDMA-related hyperpyrexia. Dantrolene's first reported use for a patient with hyperpyrexia induced by MDMA was in $1992^{14}$ and numerous reports of dantrolene use for this indication have followed, some advocating for ${ }^{8,15-21}$ and some cautioning against ${ }^{22-24}$ its use. Dantrolene is currently recommended for MDMAinduced hyperpyrexia by several poison control centres. ${ }^{17,25,26}$ However, despite striking clinical similarities between the MDMA-related hyperpyrexic syndrome and malignant hyperpyrexia, evidence that these syndromes share the same mechanism is lacking and dantrolene's role in the management of MDMA-related hyperpyrexia remains controversial. ${ }^{22}$

In an effort to prove the potential link between malignant hyperpyrexia and MDMA-induced hyperpyrexia, Fiege and colleagues ${ }^{13}$ administered intravenous MDMA to malignant hyperpyrexia-susceptible swine and induced signs of malignant hyperpyrexia that could be partially counteracted with dantrolene combined with sodium bicarbonate and hyperventilation. This experiment has been criticized because of its multimodal treatment and because hypermetabolic effects were also induced by MDMA in nonmalignant hyperpyrexiasusceptible swine. ${ }^{27}$ Denborough and Hopkinson ${ }^{28}$ injected MDMA into malignant hyperpyrexia-susceptible muscle 
specimens and measured increased myoplasmic calcium concentrations (as would be seen in malignant hyperpyrexia), although the work has been criticized for the use of MDMA concentrations up to 2000-fold higher than those seen in fatal cases. ${ }^{29}$ It should also be noted that there have been 2 documented cases of hyperpyrexia (one from MDMA and another from MDA [methylenedioxyamphetamine], a closely related compound) in which testing for malignant hyperpyrexiasusceptibility was found to be negative. ${ }^{30,31}$ To our knowledge, there are no documented cases of a positive genetic test for malignant hyperpyrexia in a person who developed hyperpyrexia from MDMA.

The rationale for using dantrolene to treat MDMArelated hyperpyrexia has been questioned by toxicologists who believe that hyperpyrexia caused by MDMA is centrally mediated via serotonin, whereas dantrolene acts peripherally at skeletal muscle. ${ }^{6}$ It has been conjectured that the apparent benefit of using dantrolene to treat MDMA-induced hyperpyrexia is secondary to a reduction in heat generation in skeletal muscle without treatment of the centrally mediated cause. This logic is contested, though, as dantrolene has been shown to be ineffective in patients with heat stroke. ${ }^{32}$ Furthermore, benefit has not been seen with nondepolarizing neuromuscular agents, which would be expected to be just as efficacious in reducing skeletal muscle rigidity and heat production in patients with serotonin syndrome. ${ }^{33}$

Further theories that have been proposed to explain the seemingly random occurrence of hyperpyrexia in MDMA users include elevated core temperature secondary to excessive dancing ${ }^{34,35}$ and genetic polymorphism of P450 isoenzyme CYP2D6, ${ }^{36}$ both of which lack conclusive evidence. ${ }^{37,38}$

In light of the controversy surrounding the use of dantrolene for MDMA-related hyperpyrexia, we conducted a systematic review to summarize the reported experience with the use of dantrolene for hyperpyrexia induced by MDMA in humans.

\section{METHODS}

\section{Data sources}

The search was carried out independently by 2 investigators (B.E.G. and M.O.W.). We conducted a systematic computerized MEDLINE search from 1950 to November 2008 to identify all reports of MDMAinduced hyperpyrexia in humans. A case was defined as a single exposure to MDMA resulting in hyperpyrexia; thus, one publication could result in several cases. We applied the following algorithm in medical subject headings and in free text: " $n$-methyl-3,4-methylenedioxyamphetamine" or "MDMA" or "ecstasy") and "case report." We also combined the terms ("n-methyl3,4-methylenedioxyamphetamine" or "MDMA" or "ecstasy") and "dantrolene" to identify any published human trials or observational research. These terms were combined and the results were recorded. A similar algorithm was applied to Embase from 1980 to November 2008. Furthermore, we searched references of all articles retrieved to increase the sensitivity of our search. Any disagreements regarding article eligibility were resolved by consensus. All relevant articles were considered, independent of language of publication.

\section{Study selection}

A case report or series was included if it reported the following: known exposure to MDMA, documented hyperpyrexia $\left(\geq 38^{\circ} \mathrm{C}\right)$, patient survival at least until time of initial assessment and management by medical personnel, and patient age 15 years or older. Cases were excluded if another medical condition may have accounted for the hyperpyrexia or if there was exposure to co-ingestants other than alcohol, benzodiazepines, opiates or cannabis. Although it would have been ideal to exclude all cases with co-ingestants, this was not realistic because of the high prevalence of polydrug use among MDMA users. Thus, cases involving concomitant use of alcohol, benzodiazepines, opiates and cannabis were included, as these drugs were viewed as unlikely to cause hyperpyrexia. We planned to include all human trials that reported on the use of dantrolene for MDMA-related hyperpyrexia.

\section{Quality assessment}

All cases were assessed in a blinded fashion by 2 authors (M.O.W. and B.E.G.). Because no validated quality scoring system exists for the reporting of case reports, cases were ranked according to 4 quality criteria that we deemed relevant for this type of case: 1 ) the reporting of more than 1 temperature value (temperatures before and after administration of dantrolene were required in cases involving dantrolene use), 2) an attempt to exclude other causes of hyperpyrexia as demonstrated by laboratory testing, imaging or both, 3) confirmation of MDMA ingestion by analysis and detection of either the presence of MDMA or its metabolites in body fluid or direct analysis of ingested substance and 4) docu- 
mentation of the presence or absence of complications resulting from the suspected MDMA-related event. A score of 3 or greater indicated good report quality.

\section{Data extraction}

The following data were abstracted systematically onto a computerized Excel worksheet: article author and date of publication, patient age and sex, treatment with dantrolene and dose used, peak temperature, peak creatine kinase level, all complications associated with MDMA toxicity, adverse events attributed to dantrolene, survival, laboratory confirmation of MDMA exposure and the clinicians' impressions of the effectiveness of the dantrolene treatment. Cases were grouped into 3 temperature ranges (chosen a priori): $38-39.9^{\circ} \mathrm{C}$, $40-41.9^{\circ} \mathrm{C}$ and $42^{\circ} \mathrm{C}$ or higher. These temperature ranges have been used previously by other authors. ${ }^{8}$ Outcomes were classified as follows: death; survival with severe sequelae (defined as evidence of end-organ damage such as acute kidney injury, hepatotoxicity, coagulopathy, arrhythmias, cerebral or cardiac ischemic events, intracranial hemorrhage, acute respiratory distress syndrome, status epilepticus or the use of vasopressors for hemodynamic support); or survival with moderate or minor sequelae (rhabdomyolysis without organ involvement, isolated seizures, transient metabolic acidosis, isolated thrombocytopenia, hypoglycemia or asymptomatic electrolyte imbalances). Reported complications that occurred before the patient's

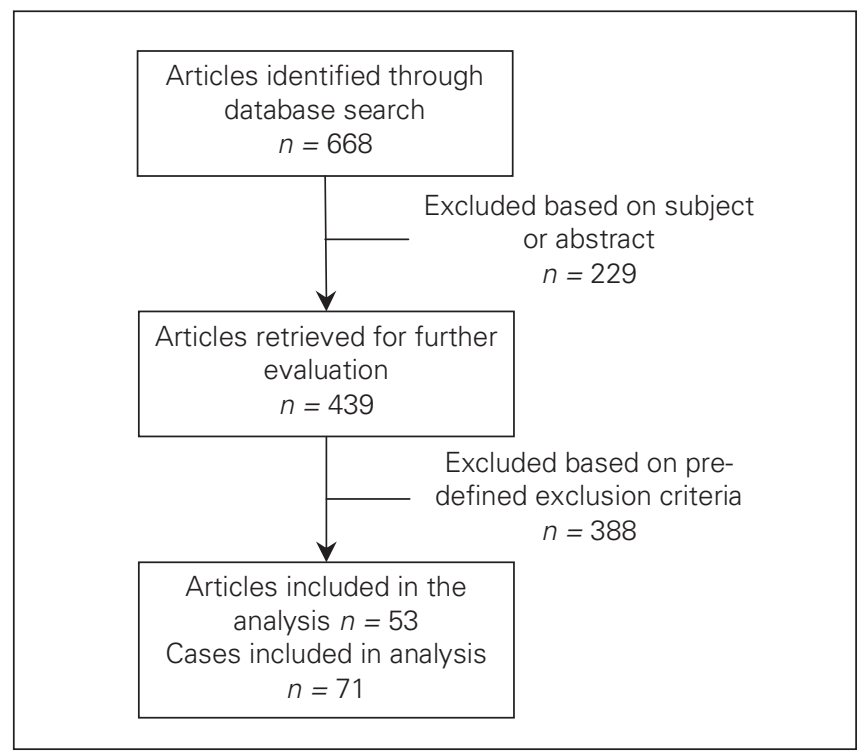

Fig. 1. Schematic diagram of search and retrieval of cases of MDMA toxicity. A case was defined as 1 toxic exposure to MDMA; thus, 1 article could contain several cases. discharge were recorded. In cases in which abnormal neurologic findings remained present at discharge we considered the patient to have "persistent neurologic sequelae." Quantity of MDMA used was not recorded because of the unknown amount of MDMA per pill ingested. Formal statistical analyses were not conducted because of the risks of reporting and publication bias. All results were reported using descriptive statistics.

\section{RESULTS}

Our search strategy yielded 668 documents, of which 53 articles describing 71 cases of MDMA-related hyperpyrexia met our inclusion and exclusion criteria (Fig. 1). No clinical trials, randomized controlled trials, observational studies or meta-analyses were identified in the search. Of the 71 cases, 26 involved the use of dantrolene $\mathrm{e}^{14-16,18,19,23,30,33,39-56}$ and 45 did not involve the reported use of dantrolene $e^{9,37,41,56-81}$ (the dantrolene cases are summarized in Appendix 1 and the nondantrolene cases in Appendix 2, both available at www.cjem -online.ca). Characteristics of cases were similar between groups (Table 1). The mean patient age was 21.3 (standard deviation 3.7) years in the dantrolene group and 21.2 (standard deviation 4.3) years in the no dantrolene group. The median age in both groups was 20 years. The proportion of male patients was $80.8 \%$ in the dantrolene group and $68.2 \%$ in the no dantrolene group. The mean and median maximum temperatures were $41.4^{\circ} \mathrm{C}$ and $42.0^{\circ} \mathrm{C}$, respectively, in the dantrolene group and $40.7^{\circ} \mathrm{C}$ and $40.7^{\circ} \mathrm{C}$ in the no dantrolene group. The cooling method and use of neuromuscular paralysis were often not mentioned, making it impossible

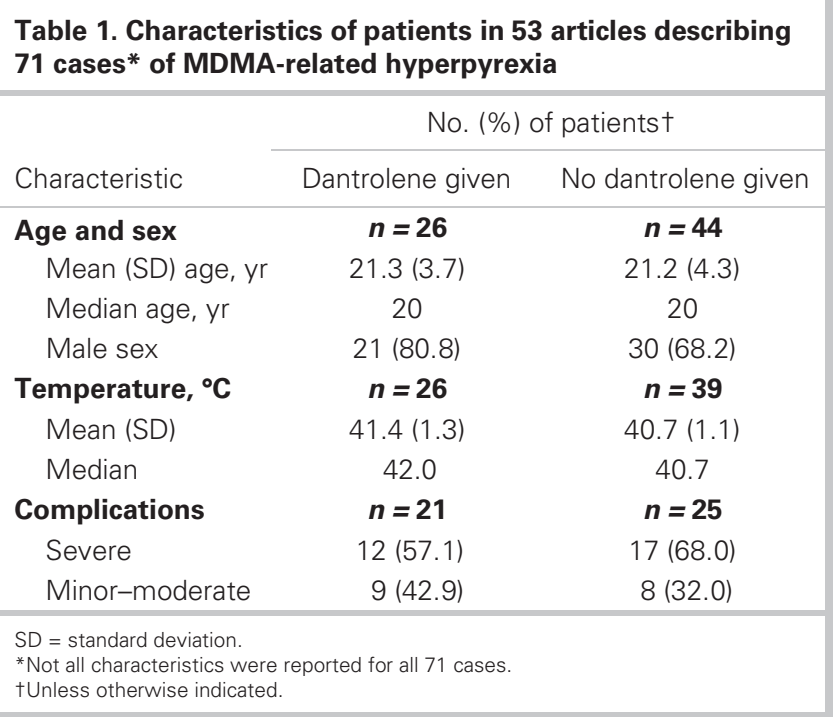


to compare rates of these interventions between groups. Cyproheptadine is an antihistamine with serotonin antagonist properties that has been used as an antidote for patients with serotonin syndrome. ${ }^{5}$ There were no reports of cyproheptadine use in this case series.

In the case reports examined, MDMA-related hyperpyrexia was associated with rhabdomyolysis, hyperkalemia, shock, acidosis, hypo- and hypercalcemia, hyponatremia, hypoglycemia, coagulopathy, seizures, acute kidney injury, hepatotoxicity, pancreatic necrosis, cerebral edema, cardiac and cerebral ischemia, acute respiratory distress syndrome, pulmonary edema and injury, gluteal compartment syndrome, multifocal hemorrhages, cardiac conduction abnormalities and arrhythmias, persistent neurologic deficits and death. With the exception of "persistent neurologic sequelae" described in 2 patients at discharge, the long-term sequelae of MDMA-related hyperpyrexia is unknown. A possible association between dantrolene and transient hypoglycemia was described in one case report; ${ }^{45}$ otherwise, no adverse events were attributed to dantrolene in the case reports.

There were 25 fatal cases including 5 of $26(19 \%)$ in the dantrolene group and 20 of $45(44 \%)$ in the no dantrolene group. For the temperature categories of $42^{\circ} \mathrm{C}$ or higher, $40-41.9^{\circ} \mathrm{C}$ and $38-39.9^{\circ} \mathrm{C}$, survival in the dantrolene group was 8 of $13(62 \%), 10$ of $10(100 \%)$ and 3 of $3(100 \%)$, respectively, whereas in the no dantrolene group survival was 0 of $4(0 \%), 15$ of 27

\begin{tabular}{|c|c|c|}
\hline \multirow[b]{2}{*}{ Survival } & \multicolumn{2}{|c|}{ No. of survivors (\%) } \\
\hline & Dantrolene & No dantrolene \\
\hline Total survival & $21 / 26$ (80.8) & $25 / 45(55.6)$ \\
\hline Survival $\geq 42^{\circ} \mathrm{C}$ & $8 / 13 \quad(61.5)$ & $\begin{array}{ll}0 / 4 & (0.0)\end{array}$ \\
\hline Severe complications & 6/8 (75.0) & - \\
\hline Mild-moderate complications & $2 / 8 \quad(25.0)$ & - \\
\hline Survival $40-41.9^{\circ} \mathrm{C}$ & $10 / 10(100.0)$ & $15 / 27(55.6)$ \\
\hline Severe complications & $5 / 10 \quad(50.0)$ & $12 / 15(80.0)$ \\
\hline Mild-moderate complications & $5 / 10 \quad(50.0)$ & $3 / 15(20.0)$ \\
\hline Survival $38.0-39.9^{\circ} \mathrm{C}$ & 3/3 (100.0) & $7 / 8(87.5)$ \\
\hline Severe complications & $1 / 3$ & $3 / 7(42.9)$ \\
\hline Mild-moderate complications & $2 / 3 \quad(66.7)$ & $4 / 7(57.1)$ \\
\hline $\begin{array}{l}\text { Survival: temperature identified } \\
\text { as }>38^{\circ} \mathrm{C}^{*}\end{array}$ & - & $3 / 6(50.0)$ \\
\hline Severe complications & - & $2 / 3(66.6)$ \\
\hline Mild-moderate complications & - & 1/3 (33.3) \\
\hline
\end{tabular}

*In the following case reports, patients were described as being hyperpyrexial, but the authors did not cite a specific temperature: Patel et al. (first case): ${ }^{37}$ Karlovsek et al., ${ }^{60}$ Ben-Abraham et al. (3 cases). ${ }^{63}$ Garcia-Repetto et al. (first case). ${ }^{65}$
$(56 \%)$ and 7 of $8(88 \%)$ (Table $\left.2^{37,60,63,65}\right)$. Survivors in the no dantrolene group were more likely to suffer severe sequelae than those in the dantrolene group. This was most apparent in the temperature range of $40-41.9^{\circ} \mathrm{C}$. The dosing of dantrolene varied considerably between cases; however, the most common dose used was $1 \mathrm{mg} / \mathrm{kg}$ or $80 \mathrm{mg}$ intravenously, with repeated doses as necessary.

We rated the reports of 25 of 71 cases as "high quality" (quality score of $\geq 3$ ). The $\kappa$ value for interrater agreement for quality scores was 0.79 . A sensitivity analysis restricted to high-quality case reports showed an overall survival rate of $76 \%$ in the dantrolene group compared with $66 \%$ in the no dantrolene group despite a higher mean temperature in the dantrolene group $\left(41.7^{\circ} \mathrm{C} \mathrm{v} .40 .7^{\circ} \mathrm{C}\right.$ in the no dantrolene group). The survival rate in the case reports deemed high quality with severe $\left(\geq 40^{\circ} \mathrm{C}\right)$ and extreme $\left(\geq 42^{\circ} \mathrm{C}\right)$ hyperpyrexia was also higher in the dantrolene group ( $83 \%$ v. $79 \%)$ than in the no dantrolene group (50\% v. $0 \%)$.

In 10 of the 26 cases reporting dantrolene use, the authors indicated that they believed dantrolene was effective; in the remaining 16 cases, the authors either did not state an opinion or were unsure. One report included a cooling graph that indicated a significant drop in temperature on 2 separate occasions after dantrolene was administered. ${ }^{19}$

\section{DISCUSSION}

For most rare toxicologic emergencies, definitive evidence from randomized controlled trials or even observational studies is not available, leaving the clinician to base management decisions on physiologic grounds, consensus statements and case reports. In the case of MDMA-related hyperpyrexic syndrome, animal toxicology studies have neither confirmed nor refuted the possible link between MDMA and malignant hyperpyrexia, and cannot be used to justify the use of dantrolene for this indication. This systematic review summarizes the current state of the evidence concerning the use of dantrolene for MDMA-related hyperpyrexia in humans. We found 71 cases of MDMA-related hyperpyrexia, of which dantrolene was used in 26. There were no randomized controlled trials, clinical trials or observational studies on this subject.

Commonly reported complications of MDMArelated hyperpyrexia included rhabdomyolysis, acute kidney injury, hepatotoxicity, coagulopathy, seizures, shock, cerebral injuries and electrolyte abnormalities (Box 1). It is possible that the well-known effects of 
MDMA on serum sodium concentrations ${ }^{82}$ may have played a role in the reported complications of cerebral edema, seizures and persistent neurologic sequelae. There were 25 deaths reported in the case reports examined; of these, 5 of the patients had been given dantrolene and 20 had not. Therefore, although rare, MDMArelated hyperpyrexia can be associated with severe complications or death.

Dantrolene has been shown to be associated with muscle weakness and phlebitis, and, in rare cases, respiratory failure, gastrointestinal upset and excessive secretions. ${ }^{83}$ In our review none of these, nor any other side effects, were attributed to dantrolene, with the exception of a single case of transient hypoglycemia possibly related to dantrolene use. In view of these data, we conclude that dantrolene appears to be safe for the treatment of MDMA-induced hyperpyrexia.

In the 71 cases identified in this review, those reporting dantrolene use had a higher survival rate $(81 \% \mathrm{v}$. $56 \%$; Table 2$)$ and fewer severe sequelae $(57 \%$ v. $68 \%$; Table 1) than those not using dantrolene. In cases with peak temperatures $42^{\circ} \mathrm{C}$ or higher, patients who were given dantrolene had a $62 \%$ survival rate compared with no survivors in the no dantrolene group. In cases with peak temperatures $40-41.9^{\circ} \mathrm{C}$, patients given dantrolene had an increased survival rate $(100 \%$ v. $57 \%)$ and a lower rate of severe sequelae ( $42 \%$ v. $81 \%)$. Finally, in cases with peak temperatures of $38-39.9^{\circ} \mathrm{C}$, patients given dantrolene had a slightly greater survival rate $(100 \%$ v. $88 \%)$ and fewer severe sequelae (33\% v. $43 \%)$.

These data suggest that dantrolene may reduce mortality and complications in patients with MDMA-related hyperpyrexic syndrome. However this conclusion must

\section{Box 1. Complications of MDMA-related hyperpyrexic} syndrome

- Delirium and agitation

- Seizures

- Rhabdomyolysis

- Hyperkalemia

- Arrhythmias

- Metabolic acidosis

- Myocardial ischemia

- Cerebral ischemia

- Cerebral edema

- Acute kidney injury

- Pulmonary edema

- Acute respiratory distress syndrome

- Hepatotoxicity

- Coagulopathy

- Shock necessitating vasotropic/inotropic support be viewed with caution as it is based entirely on case reports, which are susceptible to reporting and publication bias. It is possible that cases involving survival with standard therapy or those involving failure of dantrolene therapy are less likely to be reported or published.

A second limitation of our review is that, to our knowledge, no formal quality assessment tool for the evaluation of case reports has been published. To address this issue, we developed our own face-valid quality assessment tool based on the presence or absence of characteristics we deemed important for judging the quality of case reports. Our $\kappa$ value of 0.79 indicated substantial interrater agreement. A sensitivity analysis restricted to high-quality case reports also suggested that dantrolene was associated with increased survival.

\section{CONCLUSION}

This is the first systematic compilation of all case reports of MDMA-related hyperpyrexic syndrome. The current state of the evidence for the treatment of MDMA-related hyperpyrexia with dantrolene does not allow for definitive proof of causality, as it is limited to case reports. However, given the low incidence of hyperpyrexia related to MDMA it is unlikely that more definitive evidence from randomized controlled trials or even quasi-experimental trials will ever become available. The purpose of this review was not to prove causality but rather to help clinicians to make evidenceinformed decisions regarding MDMA-related hyperpyrexic syndrome and the indication for treatment with dantrolene, a subject previously shrouded in ambiguity. Although limited by possible reporting or publication bias, our findings suggest that dantrolene is rarely associated with side effects when used for patients with MDMA-related hyperpyrexia and may lower mortality rates and reduce the incidence of severe complications especially in patients with severe $\left(\geq 40^{\circ} \mathrm{C}\right)$ or extreme $\left(\geq 42^{\circ} \mathrm{C}\right)$ hyperpyrexia.

Acknowledgements: The authors acknowledge the significant efforts of Julie Mason, Chilliwack General Hospital librarian, in helping to obtain numerous case reports.

Competing interests: None declared.

\section{REFERENCES}

1. Merck E, inventor. Varfeharen Zur Darstellung Von Alkyloxyaryl-Dialyoxyaryl-Und Alkylenedioxyarylaminopropanen 
Bzw. Deren Am Stickstoff Monoalkylierten. German patent 274350. 1914.

2. Adlaf EM, Begin P, Sawka E. Canadian Addiction Survey (CAS): a national survey of Canadians' use of alcobol and other drugs: prevalence of use and related harms, detailed report. Ottawa (ON): Canadian Centre on Substance Abuse; 2005.

3. Eaton DK, Kann L, Kinchen S, et al. Youth risk behavior surveillance - United States, 2007. MMWR Surveill Summ 2008;57:1-131.

4. Gore SM. Fatal uncertainty: death-rate from use of ecstasy or heroin. Lancet 1999;354:1265-6

5. Boyer EW, Shannon M. The serotonin syndrome. $N$ Engl 7 Med 2005;352:1112-20.

6. Kalant H. The pharmacology and toxicology of "ecstasy" (MDMA) and related drugs. CMAJ 2001;165:917-28.

7. Iravani MM, Asari D, Patel J, et al. Direct effects of 3 , 4-methylenedioxymethamphetamine (MDMA) on serotonin or dopamine release and uptake in the caudate putamen, nucleus accumbens, substantia nigra pars reticulata, and the dorsal raphe nucleus slices. Synapse 2000;36:275-85.

8. Hall AP, Henry JA. Acute toxic effects of "ecstacy" (MDMA) and related compounds: overview of pathophysiology and clinical management. Br 7 Anaesth 2006;96:678-85.

9. Henry JA, Jeffreys KJ, Dawling S. Toxicity and deaths from 3,4-methylenedioxymethamphetamine ("ecstasy"). Lancet 1992;340:384-7.

10. Larner AJ. Dantrolene and "ecstasy" overdose. Anaesthesia 1993;48:179-80.

11. Stone RJ. Treatment of "ecstasy" overdose with dantrolene. Anaesthesia 1993;48:83.

12. Wappler F, Fiege M, Schulte am Esch J. Pathophysiological role of the serotonin system in malignant hyperthermia. $\mathrm{Br} \mathrm{J}$ Anaesth 2001;87:794-8.

13. Fiege M, Wappler F, Weisshorn R, et al. Induction of malignant hyperthermia in susceptible swine by 3,4-methylenedioxymethamphetamine ("ecstasy"). Anesthesiology 2003;99: 1132-6.

14. Singarajah C, Lavies NG. An overdose of ecstasy: a role for dantrolene. Anaesthesia 1992;47:686-7.

15. Logan AS, Stickle B, O'Keefe N, et al. Survival following "ecstasy" ingestion with a peak temperature of 42 degrees $\mathrm{C}$. Anaesthesia 1993;48:1017-8.

16. Moon J, Cros J. Role of dantrolene in the management of the acute toxic effects of ecstasy (MDMA). Br J Anaesth 2007; 99:146.

17. Vale A. Amfetamines including MDMA (ecstasy). Medicine 2007;35:582.

18. Mallick A, Bodenham AR. MDMA induced hyperthermia: a survivor with an initial body temperature of 42.9 degrees $\mathrm{C}$. J Accid Emerg Med 1997;14:336-8.

19. Webb C, Williams V. Ecstasy intoxication: appreciation of complications and the role of dantrolene. Anaesthesia 1993; 48:542-3.

20. Tehan B. Ecstasy and dantrolene. BMJ 1993;306:146.

21. Bodenham AR, Mallick A. New dimensions in toxicology: hyperthermic syndrome following amphetamine derivatives. Intensive Care Med 1996;22:622-4.

22. Duffy MR, Ferguson C. Role of dantrolene in treatment of heat stroke associated with ecstasy ingestion. Br 7 Anaesth 2007;98:148-9.

23. Watson JD, Ferguson C, Hinds CJ, et al. Exertional heat stroke induced by amphetamine analogues. Does dantrolene have a place? Anaesthesia 1993;48:1057-60.

24. Barrett PJ. Ecstasy and dantrolene. BMJ 1992;305:1225.

25. Hallucinogenic amphetamines. In: Poison management manual. 4th ed. Vancouver (BC): BC Drug and Poison Information Centre; 1997. p. 70.

26. Toxbase. Monograph MDMA. Available: www.toxbase.co.uk (accessed 2009 Mar. 25)

27. Rusyniak DE, Banks ML, Mills EM, et al. Dantrolene use in 3,4-methylenedioxymethamphetamine (ecstasy)-mediated hyperthermia. Anesthesiology 2004;101:263, author reply 264.

28. Denborough MA, Hopkinson KC. Dantrolene and "ecstasy." Med J Aust 1997;166:165-6.

29. Hall AP. Dantrolene and "ecstasy." Med J Aust 1997;167: 506-7.

30. Strobbe L, de Jaer CP, Louwerse ES, et al. [Fatal ecstasy intoxication in a 22-year-old man] [article in Dutch]. Ned Tijdschr Geneeskd 2007;151:2295.

31. Tehan B, Hardern R, Bodenham A. Hyperthermia associated with 3,4-methylenedioxyethamphetamine ("Eve"). Anaesthesia $1993 ; 48: 507-10$.

32. Bouchama A, Cafege A, Devol EB, et al. Ineffectiveness of dantrolene sodium in the treatment of heatstroke. Crit Care Med 1991;19:176-80.

33. Dar KJ, McBrien ME. MDMA induced hyperthermia: report of a fatality and review of current therapy. Intensive Care Med 1996;22:995-6.

34. Gordon CJ, Watkinson WP, O'Callaghan JP, et al. Effects of 3,4-methylenedioxymethamphetamine on autonomic thermoregulatory responses of the rat. Pharmacol Biochem Behav 1991;38:339-44.

35. Green AR, Cross AJ, Goodwin GM. Review of the pharmacology and clinical pharmacology of 3,4-methylenedioxymethamphetamine (MDMA or "ecstasy"). Psychopharmacology (Berl) 1995;119:247-60.

36. Colado MI, Williams JL, Green AR. The hyperthermic and neurotoxic effects of "ecstasy" (MDMA) and 3,4 methylenedioxyamphetamine (MDA) in the dark agouti (DA) rat, a model of the CYP2D6 poor metabolizer phenotype. $\mathrm{Br} \mathrm{J}$ Pharmacol 1995;115:1281-9.

37. Patel MM, Belson MG, Longwater AB, et al. Methylenedioxymethamphetamine (ecstasy)-related hyperthermia. 7 Emerg Med 2005;29:451-4.

38. de la Torre R, Farre M. Neurotoxicity of MDMA (ecstasy): the limitations of scaling from animals to humans. Trends Pharmacol Sci 2004;25:505-8.

39. Grunau BE, Wiens MO, Greidanus M. Dantrolene for the treatment of MDMA toxicity. CJEM 2010;12:457-9.

40. Kunitz O, Ince A, Kuhlen R, et al. Hyperpyrexia and rhabdomyolysis after ecstasy (MDMA) intoxication. Anaesthesist 2003;52:511-5.

41. Greene SL, Dargan PI, O'connor N, et al. Multiple toxicity from 3,4-methylenedioxymethamphetamine ("ecstasy"). Am 7 Emerg Med 2003;21:121-4.

42. Ferrie R, Loveland RC. Bilateral gluteal compartment syndrome after "ecstasy" hyperpyrexia. J R Soc Med 2000;93:260.

43. Ramcharan S, Meenhorst PL, Otten JM, et al. Survival after massive ecstasy overdose. J Toxicol Clin Toxicol 1998;36:727-31.

44. Williams A, Unwin R. Prolonged elevation of serum creatine kinase $(\mathrm{CK})$ without renal failure after ingestion of ecstasy. Nephrol Dial Transplant 1997;12:361-2.

45. Montgomery H, Myerson S. 3,4-methylenedioxymethamphetamine (MDMA, or "ecstasy") and associated hypoglycemia. Am J Emerg Med 1997;15:218.

46. Murthy BV, Wilkes RG, Roberts NB. Creatine kinase isoform changes following ecstasy overdose. Anaesth Intensive Care 1997;25:156-9.

47. Coore JR. A fatal trip with ecstasy: a case of 3,4-methylenedioxymethamphetamine/3,4- methylenedioxyamphetamine 
toxicity. $7 R$ Soc Med 1996;89:51P-2P.

48. Ellis AJ, Wendon JA, Portmann B, et al. Acute liver damage and ecstasy ingestion. Gut 1996;38:454-8.

49. Hall AP, Lyburn ID, Spears FD, et al. An unusual ease of ecstasy poisoning. Intensive Care Med 1996;22:670-1.

50. Demirkiran M, Jankovic J, Dean JM. Ecstasy intoxication: an overlap between serotonin syndrome and neuroleptic malignant syndrome. Clin Neuropharmacol 1996;19:157-64.

51. Wake D. Ecstasy overdose: a case study. Intensive Crit Care Nurs 1995;11:6-9.

52. Roberts L, Wright H. Survival following intentional massive overdose of "ecstasy." J Accid Emerg Med 1994;11:53-4.

53. Walsh T, Carmichael R, Chestnut J. A hyperthermic reaction to "ecstasy." Br 7 Hosp Med 1994;51:476.

54. Nimmo SM, Kennedy BW, Tullett WM, et al. Druginduced hyperthermia. Anaesthesia 1993;48:892-5.

55. Campkin NT, Davies UM. Another death from ecstacy. $7 R$ Soc Med 1992;85:61.

56. Counselman FL. Rhabdomyolysis. In: Tintinalli JE, Kelen GD, Stapczynski JS, editors. Tintinalli's emergency medicine: a comprebensive study guide. 6th ed. Columbus $(\mathrm{OH})$ : McGraw-Hill; 2004.

57. Dahl MK, Johansen SS, Ramlau J, et al. Survival after severe ecstasy intoxication. Ugeskr Laeger 2008;170:3678.

58. Archer T. Ecstasy toxicity and the cooling factor. Emerg Med 72008;25:534.

59. Kunsdorf-Wnuk A, Musiol E, Karpel E, et al. [Rhabdomyolysis, disseminated intravascular coagulation and acute renal failure after severe narcotics intoxication (MDMA, THC, amphetamine)] [article in Polish]. Pol Merkur Lekarski 2005;18:436-9.

60. Karlovsek MZ, Alibegovic A, Balazic J. Our experiences with fatal ecstasy abuse (two case reports). Forensic Sci Int 2005; 147(Suppl):S77-80.

61. Raviña P, Quiroga JM, Raviña T. Hyperkalemia in fatal MDMA ("ecstasy") toxicity. Int J Cardiol 2004;93:307-8.

62. Bordo DJ, Dorfman MA. Ecstasy overdose: rapid cooling leads to successful outcome. Am J Emerg Med 2004;22:326-7.

63. Ben-Abraham R, Szold O, Rudick V, et al. "Ecstasy" intoxication: life-threatening manifestations and resuscitative measures in the intensive care setting. Eur 7 Emerg Med 2003;10:309-13.

64. Hinkelbein J, Gabel A, Volz M, et al. Suicide attempt with high-dose ecstasy. Anaesthesist 2003;52:51-4.

65. Garcia-Repetto R, Moreno E, Soriano T, et al. Tissue concentrations of MDMA and its metabolite MDA in three fatal cases of overdose. Forensic Sci Int 2003;135:110-4.

66. Finsterer J, Stöllberger C, Steger C, et al. Long lasting impaired cerebral blood flow after ecstasy intoxication. Psychiatry Clin Neurosci 2003;57:221-5.
67. Sue YM, Lee Y, Huang J. Acute hyponatremia, seizure, and rhabdomyolysis after ecstasy use. 7 Toxicol Clin Toxicol 2002;40:931-2.

68. Nielsen S, Lundemose JB, Simonsen MS, et al. Fatal ecstasy intoxication. Ugeskr Laeger 2001;163:2253-5.

69. Trejo Gutiérrez O, Ortega Romero M, Perea Gainza M, et al. Multiple organ failure associated with use of ecstasy. Rev Clin Esp 2001;201:108-9.

70. Franceschini E, Baronti R, Spaggiari C. Case report: acute poisoning with ecstasy. Minerva Pediatr 2000;52:547-8.

71. Shannon M. Methylenedioxymethamphetamine (MDMA, "ecstasy"). Pediatr Emerg Care 2000;16:377-80.

72. Mueller PD, Korey WS. Death by "ecstasy": The serotonin syndrome? Ann Emerg Med 1998;32:377-380.

73. Drake WM, Broadhurst PA. QT-interval prolongation with ecstasy. S Afr Med J 1996;86:180-1.

74. Lehmann ED, Thom CH, Croft DN. Delayed severe rhabdomyolysis after taking "ecstasy" Postgrad Med J 1995;71:186-7.

75. Satchell SC, Connaughton M. Inappropriate antidiuretic hormone secretion and extreme rises in serum creatinine kinase following MDMA ingestion. Br J Hosp Med 1994;51:495.

76. Barrett PJ, Taylor GT. "Ecstasy" ingestion: a case report of severe complications. 7R Soc Med 1993;86:233-4.

77. Fahal IH, Sallomi DF, Yaqoob M, et al. Acute renal failure after ecstasy. BMJ 1992;305:29.

78. Screaton GR, Singer M, Cairns HS, et al. Hyperpyrexia and rhabdomyolysis after MDMA ("ecstasy") abuse. Lancet 1992;339:677-8.

79. Chadwick IS, Curry PD, Linsley A, et al. Ecstasy, 3-4 methylenedioxymethamphetamine (MDMA), a fatality associated with coagulopathy and hyperthermia. J R Soc Med 1991;84:371.

80. Brown C, Osterloh J. Multiple severe complications from recreational ingestion of MDMA ("ecstasy"). JAMA 1987; 258:780-1.

81. Simpson DL, Rumack BH. Methylenedioxyamphetamine. clinical description of overdose, death, and review of pharmacology. Arch Intern Med 1981;141:1507-9.

82. Hartung TK, Schofield E, Short AI, et al. Hyponatraemic states following 3,4-methylenedioxymethamphetamine (MDMA, “ecstasy") ingestion. QJM 2002;95:431-7.

83. Brandom BW, Larach MG. The North American malignant hyperthermia registry: reassessment of the safety and efficacy of dantrolene. Anesthesiology 2002;96:A1199.

Correspondence to: Dr. Matthew Wiens, 45600 Menholm Rd., Department of Pharmacy, Chilliwack General Hospital, Chilliwack BC V2P 1P7; matthew.wiens@fraserhealth.ca 


\begin{tabular}{|c|c|c|c|c|c|c|}
\hline \multicolumn{7}{|c|}{ Appendix 1. Characteristics of included cases of dantrolene for MDMA-related hyperpyrexia } \\
\hline Case & Temp., & Age/sex & Reported acute complications & Complications* & Survival & $\begin{array}{l}\text { Quality } \\
\text { score }\end{array}$ \\
\hline Grunau et al..$^{39}$ & 42.2 & $31 / \mathrm{M}$ & Rhabdomyolysis $\ddagger$ & M & Y & 4 \\
\hline Moon and $\mathrm{Cros}^{16}$ & 41.7 & $21 / \mathrm{M}$ & None & M & Y & 1 \\
\hline Strobbe et al. ${ }^{30}$ & 42.0 & $22 / \mathrm{M}$ & $\begin{array}{l}\text { AKI, hyperkalemia, vasotropic/inotropic support } \\
\text { required, hepatotoxicity, coagulopathy, cerebral } \\
\text { edema, acidosis, rhabdomyolysis }\end{array}$ & $\mathrm{n} / \mathrm{a}$ & N & 3 \\
\hline Kunitz et al. ${ }^{40}$ & 43.0 & $21 / \mathrm{M}$ & Coagulopathy, hepatotoxicity, AKI, rhabdomyolysis & S & Y & 4 \\
\hline Greene et al. ${ }^{41}$ & 41.6 & $18 / \mathrm{M}$ & $\begin{array}{l}\text { Acidosis, vasotropic/inotropic support required, AKI, } \\
\text { hepatotoxicity, myoglobinuria, rhabdomyolysis }\end{array}$ & S & Y & 4 \\
\hline Ferrie and Loveland ${ }^{42}$ & 43.0 & 19/M & $\begin{array}{l}\text { Acidosis, hyperkalemia, AKI, coagulopathy, bilateral } \\
\text { gluteal compartment syndrome, myoglobinuria, } \\
\text { rhabdomyolysis }\end{array}$ & S & Y & 3 \\
\hline Ramcharan et al..$^{43}$ & 38.7 & $30 / \mathrm{M}$ & Seizure, acidosis & M & Y & 4 \\
\hline Williams and Unwin ${ }^{44}$ & 41.9 & $25 / F$ & $\begin{array}{l}\text { Seizure, hypoglycemia, thrombocytopenia, } \\
\text { rhabdomyolysis }\end{array}$ & M & Y & 2 \\
\hline Mallick and Bodenham ${ }^{18}$ & 42.9 & 19/M & $\begin{array}{l}\text { Seizure, myoglobinuria, acidosis, hepatotoxicity, } \\
\text { vasotropic/inotropic support required, } \\
\text { rhabdomyolysis }\end{array}$ & S & Y & 4 \\
\hline $\begin{array}{l}\text { Montgomery and } \\
\text { Myerson }{ }^{45}\end{array}$ & 41.9 & $25 / F$ & Coagulopathy, hypoglycemia, seizure & S & Y & 2 \\
\hline Murthy et al. ${ }^{46}$ & 42.0 & 21/M & $\begin{array}{l}\text { Acidosis, pulmonary edema, myoglobinuria, } \\
\text { coagulopathy with multifocal hemorrhages, hypo- } \\
\text { and hypercalcemia, vasotropic/inotropic support } \\
\text { required, AKI, hepatotoxicity, rhabdomyolysis }\end{array}$ & S & Y & 3 \\
\hline Coore $^{47}$ & 43.0 & $18 / F$ & $\begin{array}{l}\text { AKI, seizure, vasotropic/inotropic support required, } \\
\text { coagulopathy, hepatotoxicity, pancreatic necrosis, } \\
\text { rhabdomyolysis }\end{array}$ & $\mathrm{n} / \mathrm{a}$ & $\mathrm{N}$ & 4 \\
\hline Dar and McBrien ${ }^{33}$ & 42.0 & $17 / \mathrm{M}$ & $\begin{array}{l}\text { Second-degree AVB, cardiac pacing required, } \\
\text { anuria, coagulopathy, acidosis }\end{array}$ & $\mathrm{n} / \mathrm{a}$ & $\mathrm{N}$ & 4 \\
\hline Ellis et al. ${ }^{48}$ & 42.0 & 19/M & $\begin{array}{l}\text { Coagulopathy, AKI, hepatotoxicity, myoglobinuria, } \\
\text { rhabdomyolysis }\end{array}$ & S & Y & 3 \\
\hline Hall et al. ${ }^{49}$ & 41.0 & 26/M & $\begin{array}{l}\text { Status epilepticus, vasotropic/inotropic support } \\
\text { required, coagulopathy, AKI, ARDS, colitis, } \\
\text { hepatotoxicity, rhabdomyolysis }\end{array}$ & S & Y & 3 \\
\hline Demirkiran et al. ${ }^{50}$ & 38.5 & $19 / F$ & $\begin{array}{l}\text { Hepatotoxicity, hyponatremia, seizure, persistent } \\
\text { neurologic sequelae, rhabdomyolysis }\end{array}$ & $\mathrm{S}$ & Y & 3 \\
\hline Wake $^{51}$ & 41.2 & 24/M & Acidosis, hyperkalemia, rhabdomyolysis & M & Y & 2 \\
\hline Roberts and Wright ${ }^{52}$ & 38.6 & $20 / \mathrm{M}$ & Seizure & M & Y & 4 \\
\hline Walsh et al..$^{53}$ & 42.0 & $20 / \mathrm{M}$ & Seizure, acidosis, hyperkalemia & M & Y & 1 \\
\hline Logan et al. ${ }^{15}$ & 42.0 & 23/M & $\begin{array}{l}\text { Acidosis, vasotropic/inotropic support required, } \\
\text { coagulopathy, rhabdomyolysis }\end{array}$ & S & Y & 4 \\
\hline Webb and Williams ${ }^{19}$ & 40.2 & 20/M & $\begin{array}{l}\text { Coagulopathy, acidosis, hypoglycemia, } \\
\text { vasotropic/inotropic support required, permanent } \\
\text { neurologic sequelae, rhabdomyolysis }\end{array}$ & $S$ & Y & 3 \\
\hline \multirow[t]{2}{*}{ Watson et al. ${ }^{23}$} & 42.0 & $16 / \mathrm{M}$ & $\begin{array}{l}\text { Acidosis, seizure, coagulopathy, cerebral edema, } \\
\text { hyperkalemia, hypoglycemia, vasotropic/inotropic } \\
\text { support required, rhabdomyolysis }\end{array}$ & $\mathrm{n} / \mathrm{a}$ & $\mathrm{N}$ & 4 \\
\hline & 40.5 & $20 / \mathrm{M}$ & None & M & Y & 4 \\
\hline Nimmo et al..$^{54}$ & 40.0 & $19 / F$ & $\begin{array}{l}\text { Seizure, coagulopathy, hyperkalemia, } \\
\text { rhabdomyolysis, cerebral edema }\end{array}$ & M & Y & 3 \\
\hline Campkin and Davies ${ }^{55}$ & 42.0 & $18 / \mathrm{M}$ & Seizure, coagulopathy, rhabdomyolysis & $\mathrm{n} / \mathrm{a}$ & $\mathrm{N}$ & 3 \\
\hline Singarajah and Lavies ${ }^{14}$ & 40.2 & $24 / \mathrm{M}$ & $\begin{array}{l}\text { Acidosis, coagulopathy, myoglobinuria, status } \\
\text { epilepticus, hyperkalemia, rhabdomyolysis }\end{array}$ & S & Y & 3 \\
\hline
\end{tabular}




\begin{tabular}{|c|c|c|c|c|c|c|}
\hline Case & ${ }^{\text {Temp., }}$ & Age/sex & Reported acute complications & Complications* & Survival & $\begin{array}{l}\text { Quality } \\
\text { score }\end{array}$ \\
\hline Dahl et al. ${ }^{57}$ & 41.4 & 20/M & $\begin{array}{l}\text { Seizure, acidosis, hyperkalemia, coagulopathy, AKI, } \\
\text { hepatotoxicity, severe diffuse cerebral injury, } \\
\text { rhabdomyolysis } \neq\end{array}$ & S & Y & 4 \\
\hline Archer $^{58}$ & 40.3 & $\mathrm{n} / \mathrm{a}$ & Seizure, third-degree AVB & $\mathrm{n} / \mathrm{a}$ & $N^{\prime \prime \prime}$ & 1 \\
\hline \multirow[t]{5}{*}{ Patel et al. ${ }^{37}$} & high§ & $20 / F$ & $\begin{array}{l}\text { Seizure, cardiac arrest, cerebral ischemia, } \\
\text { hepatotoxicity }\end{array}$ & $\mathrm{n} / \mathrm{a}$ & $N$ & 2 \\
\hline & 41.5 & 20/M & Coagulopathy, AKI, hypoglycemia, rhabdomyolysis & S & Y & 4 \\
\hline & 40.7 & $18 / \mathrm{M}$ & AKI, rhabdomyolysis & S & Y & 4 \\
\hline & 40.6 & $20 / \mathrm{M}$ & Seizure, acidosis, AKI & S & Y & 4 \\
\hline & 41.3 & $27 / M$ & None & M & Y & 4 \\
\hline Kunsdorf-Wnuk et al. ${ }^{59}$ & 39.6 & 23/M & $\begin{array}{l}\text { Coagulopathy, vaso/inotropic support required, AKI, } \\
\text { rhabdomyolysis }\end{array}$ & $S$ & Y & 4 \\
\hline Karlovsek et al. ${ }^{60}$ & high§ & $21 / \mathrm{M}$ & $\begin{array}{l}\text { Vaso/inotropic support required, coagulopathy, } \\
\text { hepatotoxicity, cerebral edema, AKI, acidosis }\end{array}$ & $\mathrm{n} / \mathrm{a}$ & $\mathrm{N}$ & 3 \\
\hline Raviña et al. ${ }^{61}$ & 41.2 & 19/M & $\begin{array}{l}\text { Vaso/inotropic support required, cardiac arrest, } \\
\text { hyperkalemia, acidosis }\end{array}$ & $\mathrm{n} / \mathrm{a}$ & $\mathrm{N}$ & 3 \\
\hline Bordo and Dorfman ${ }^{62}$ & 41.8 & $20 / F$ & None, rhabdomyolysis & M & Y & 4 \\
\hline \multirow[t]{2}{*}{ Greene et al..$^{41}$} & 43 & $20 / \mathrm{M}$ & Acidosis, hyperkalemia, PEA & $\mathrm{n} / \mathrm{a}$ & $\mathrm{N}$ & 4 \\
\hline & 38.8 & $22 / \mathrm{M}$ & $\begin{array}{l}\text { Acidosis, hyperkalemia, AKI, hepatotoxicity, } \\
\text { vaso/inotropic support required, coagulopathy, } \\
\text { myoglobinuria, rhabdomyolysis }\end{array}$ & $n / a$ & N & 4 \\
\hline \multirow[t]{3}{*}{ Ben-Abraham et al. ${ }^{63}$} & $39-41$ & $23 / F$ & Seizure, ARDS, acidosis, rhabdomyolysis & $S$ & Y & 3 \\
\hline & $39-41$ & $24 / F$ & Seizure, acidosis, hyponatremia, rhabdomyolysis & M & Y & 3 \\
\hline & $39-41$ & 21/M & $\begin{array}{l}\text { Seizure, acidosis, hepatotoxicity, thrombocytopenia, } \\
\text { rhabdomyolysis }\end{array}$ & $S$ & Y & 3 \\
\hline Hinkelbein et al. ${ }^{64}$ & 38.5 & $16 / F$ & None & M & Y & 2 \\
\hline \multirow[t]{3}{*}{ Garcia-Repetto et al. ${ }^{65}$} & high§ & $19 / F$ & AKI, "brain edema," rhabdomyolysis & $\mathrm{n} / \mathrm{a}$ & $\mathrm{N}$ & 2 \\
\hline & 41.6 & $19 / \mathrm{M}$ & $\begin{array}{l}\text { Seizure, anuria, coagulopathy, "multiorgan failure," } \\
\text { rhabdomyolysis }\end{array}$ & $\mathrm{n} / \mathrm{a}$ & N & 2 \\
\hline & 41.6 & 20/M & $\begin{array}{l}\text { Seizure, anuria, coagulopathy, "multiorgan failure," } \\
\text { rhabdomyolysis }\end{array}$ & $\mathrm{n} / \mathrm{a}$ & N & 2 \\
\hline Finsterer et al. ${ }^{66}$ & 40 & $19 / F$ & $\begin{array}{l}\text { Seizure, cerebral ischemia, AKI, hepatotoxicity, } \\
\text { ST elevation, rhabdomyolysis }\end{array}$ & S & Y & 3 \\
\hline Sue et al. ${ }^{67}$ & 39.5 & $19 / F$ & Seizure, hyponatremia, rhabdomyolysis & M & Y & 3 \\
\hline Nielsen et al. ${ }^{68}$ & 40.4 & 28/M & $\begin{array}{l}\text { Acidosis, "electrolyte imbalance," vaso/inotropic } \\
\text { support required, seizure }\end{array}$ & $\mathrm{n} / \mathrm{a}$ & N & 3 \\
\hline Trejo Gutiérrez et al. ${ }^{69}$ & 41 & $17 / \mathrm{M}$ & $\begin{array}{l}\text { AKI with acute tubular necrosis, coagulopathy, } \\
\text { hepatotoxicity, cerebral and cerebellar "atrophy," } \\
\text { rhabdomyolysis }\end{array}$ & S & Y & 3 \\
\hline Franceschini et al. ${ }^{70}$ & 40 & $16 / \mathrm{M}$ & None & M & Y & 3 \\
\hline Shannon ${ }^{71}$ & 40.6 & $21 / M$ & $\begin{array}{l}\text { Seizure, coagulopathy, hepatotoxicity, } \mathrm{AKI} \\
\text { rhabdomyolysis, persistent neurologic sequelae }\end{array}$ & S & Y & 2 \\
\hline Mueller and Korey ${ }^{72}$ & 41.7 & $20 / F$ & $\begin{array}{l}\text { Acidosis, seizure, hypoglycemia, hyperkalemia, } \\
\text { ventricular fibrillation and/or asystole, SVT, } \\
\text { vaso/inotropic support required }\end{array}$ & $\mathrm{n} / \mathrm{a}$ & $\mathrm{N}$ & 4 \\
\hline Drake and Broadhurst ${ }^{73}$ & 39.0 & $25 / \mathrm{M}$ & QT prolongation & M & Y & 0 \\
\hline Lehmann et al..$^{74}$ & 39.7 & $36 / \mathrm{M}$ & $\begin{array}{l}\text { Seizure, hyponatremia, alkalosis, myoglobinuria, } \\
\text { hepatotoxicity, rhabdomyolysis }\end{array}$ & $S$ & Y & 4 \\
\hline $\begin{array}{l}\text { Satchell and } \\
\text { Connaughton }^{75}\end{array}$ & 38.0 & $24 / F$ & Seizure, hyponatremia, rhabdomyolysis & M & Y & 3 \\
\hline Barrett and Taylor ${ }^{76}$ & 40.0 & 23/M & $\begin{array}{l}\text { Acidosis, AKI, hepatotoxicity, coagulopathy, } \\
\text { rhabdomyolysis }\end{array}$ & $S$ & Y & 3 \\
\hline Fahal et al. ${ }^{77}$ & 40.0 & 23/M & $\begin{array}{l}\text { Seizure, AKI, coagulopathy, hepatotoxicity, } \\
\text { rhabdomyolysis }\end{array}$ & $\mathrm{n} / \mathrm{a}$ & N & 3 \\
\hline
\end{tabular}




\begin{tabular}{|c|c|c|c|c|c|c|}
\hline Case & ${ }^{\text {Temp., }}$ & Age/sex & Reported acute complications & Complications* & Survival & $\begin{array}{l}\text { Quality } \\
\text { score }\end{array}$ \\
\hline \multirow[t]{7}{*}{ Henry et al. ${ }^{9}$} & 41.0 & $18 / \mathrm{M}$ & Arrhythmias, asystole & $\mathrm{n} / \mathrm{a}$ & $\mathrm{N}$ & 2 \\
\hline & 41.0 & $17 / \mathrm{M}$ & Seizures, coagulopathy & $\mathrm{n} / \mathrm{a}$ & $\mathrm{N}$ & 2 \\
\hline & 42.1 & $18 / \mathrm{M}$ & Gastrointestinal hemorrhage & $\mathrm{n} / \mathrm{a}$ & $\mathrm{N}$ & 2 \\
\hline & 41.0 & $21 / F$ & Seizure, coagulopathy, AKI, rhabdomyolysis & $\mathrm{n} / \mathrm{a}$ & $\mathrm{N}$ & 2 \\
\hline & 40.0 & 20/M & Seizure, coagulopathy, AKI, rhabdomyolysis & $\mathrm{n} / \mathrm{a}$ & $\mathrm{N}$ & 2 \\
\hline & 39.7 & $19 / F$ & Thrombocytopenia, hepatotoxicity & S & Y & 2 \\
\hline & 40.0 & 20/M & Hepatotoxicity, coagulopathy, AKI, rhabdomyolysis & S & Y & 2 \\
\hline \multirow[t]{3}{*}{ Screaton et al. ${ }^{78}$} & 43.3 & 19/M & $\begin{array}{l}\text { Coagulopathy, myoglobinuria, cerebral hemorrhage, } \\
\text { rhabdomyolysis }\end{array}$ & $\mathrm{n} / \mathrm{a}$ & N & 4 \\
\hline & 41.0 & 19/M & $\begin{array}{l}\text { Coagulopathy, AKI, bilateral lower extremity } \\
\text { compartment syndrome, SVT, rhabdomyolysis }\end{array}$ & $S$ & Y & 2 \\
\hline & 40.0 & 19/M & Coagulopathy, rhabdomyolysis & $S$ & Y & 2 \\
\hline Chadwick et al. ${ }^{79}$ & 42.0 & $16 / F$ & $\begin{array}{l}\text { Acidosis, coagulopathy, vaso/inotropic support } \\
\text { required, cerebral edema, hypoglycemia }\end{array}$ & $\mathrm{n} / \mathrm{a}$ & N & 4 \\
\hline Brown and Osterloh ${ }^{80}$ & 41.6 & $32 / F$ & Acidosis, AKI, coagulopathy, hepatotoxicity & S & Y & 3 \\
\hline Simpson and Rumack ${ }^{81}$ & 41.0 & $32 / \mathrm{M}$ & $\begin{array}{l}\text { Seizure, coagulopathy, multifocal hemorrhages, } \\
\text { acidosis, thrombocytopenia, shock, pulmonary } \\
\text { edema, cerebral edema, diarrhea, rhabdomyolysis }\end{array}$ & $\mathrm{n} / \mathrm{a}$ & $\mathrm{N}$ & 4 \\
\hline \multicolumn{7}{|c|}{$\begin{array}{l}\text { AKI = acute kidney injury; ARDS = acute respiratory distress syndrome; } A V B=\text { atrioventricular block; } M=\text { minor-moderate; } n / a=\text { not available; PEA = pulseless electrical activity; } \\
S=\text { severe; SVT = supraventricular tachycardia. } \\
\text { "Mental status changes and transient neurologic abnormalities are not included as complications. } \\
\text { tSee "Quality assessment" in the article for an explanation of the quality criteria and scoring. } \\
\text { tRhabdomyolysis defined as a } 5 \text {-fold or greater increase of serum creatine kinase over normal. } \\
\text { \$T }\end{array}$} \\
\hline
\end{tabular}

